Bulletin UASVM Food Science and Technology 70(1)/2013, 58-59

ISSN-L 2344-2344; Print ISSN 2344-2344; Electronic ISSN 2344-5300

\title{
Evaluation of the Content of Lead, Cadmium, Mercury, Arsenic, Tin, Copper and Zinc during the Production Process Flow of Tomato Broth
}

\author{
Corina ANDREI ${ }^{1)}$, Felicia ŢÂRC $\breve{A}^{2)}$ \\ ${ }^{1)}$ Faculty of Horticulture. University of Agricultural Sciences and Veterinary Medicine \\ „Ion Ionescu de la Brad” Iași, street Aleea M.Sodoveanu, No 3, Romania; corinandrei84@ yahoo.com \\ ${ }^{2)}$ ANSVSA, Aleea Sadoveanu, No. 10, Iasi; tarca_felicia@yahoo.com
}

\begin{abstract}
Heavy metals are among the largest contaminants of food products. Once metals are present in vegetables, their concentrations are rarely modified by industrial processing techniques, although in some cases washing may decrease the metal content. The main objective of this study was to quantify the effect of industrial processing on the content of lead, cadmium, mercury, arsenic, tin, copper and zinc in tomatoes and products resulting on flow technology of tomato broth. For the determination of essential elements and/or potentially toxic was use atomic absorption spectrometry. The analytical results for quantitative evaluation the concentrations of the investigated elements on the samples of tomatoes taken from the technological process of the production of tomato broth indicated the presence of $\mathrm{Pb}, \mathrm{Cd}, \mathrm{Cu}$ and $\mathrm{Zn}$ but with a level of concentration that significantly decreased in the finished product and the absence of metals $\mathrm{Hg}$ and As in all investigated samples. Effect of industrial processing on the content of tin in tomato samples analyzed was characterized by fluctuations in the residual content that led to a significant increase in concentration of $0.100 \pm 0.041 \mathrm{mg} \mathrm{kg}^{-1}$ (tomatoes - unprocessed) to $0.200 \pm 0.041 \mathrm{mg} \mathrm{kg}^{-1}$ (tomato broth).
\end{abstract}

Keywords: essential elements and/or potentially toxic, industrial processing, tomato, tomato broth

Introduction. Heavy metals are among the major contaminants of food supply and may considered the most important problem to our environment. In general, heavy metals, are not biodegradable, have long biological half-lives and have the potential for accumulation in the different body organs (Radwan and Salama, 2006).

The content of heavy metals varies significantly depending on the plant species. Tomatoes can tolerate large amounts of heavy metals without toxic effects.

Typical stages used in processing fruits and vegetables, such as washing, peeling, blanching and sterilization may change the composition of essential elements as well as of the toxic elements. Also, washing vegetables allows the diffusion of ions in the apoplast. Enrichment of food with heavy metals, may be contacted processing machines, storage in metal cans, containers alloys using heavy metals (lead, iron, chromium, aluminum, copper, zinc, tin, arsenic) corresponding uninsulated (Beceanu, 2010).

Toxic elements $(\mathrm{Pb}, \mathrm{Cd}, \mathrm{Hg})$ are chemical elements very stable, not heat or chemically degrade, but depending on how they can link to migrate.

Aims and objectives. The main objective of this study was to quantify the effect of industrial processing, including washing steps, mechanical shredding, preheating, remove residue of skin/seed, concentration and pasteurization on the content of $\mathrm{Pb}, \mathrm{Cd}, \mathrm{Hg}, \mathrm{As}, \mathrm{Sn}, \mathrm{Cu}$ and $\mathrm{Zn}$ in tomatoes and products resulting on flow technology of tomato broth.

Materials and methods. Tomatoes were collected from a processing unit of vegetables and fruits in Galati County and analyzed in five stages. For the determination of essential elements and/or potentially toxic was use atomic absorption spectrometry. Cadmium, $\mathrm{Cr}$ and $\mathrm{Pb}$ was analyzed on Graphite Furnace Atomic Absorption Spectrophotometer, $\mathrm{As}$ and $\mathrm{Hg}$ on Atomic Absorption with Hydride Generation and $\mathrm{Cu}, \mathrm{Zn}$ and $\mathrm{Sn}$ by Flame Atomic Absorption Spectrophotometry. 
Results and Discussion. The mean concentrations and standard deviation of heavy metals found in tomatoes sampled ( $\mathrm{Pb}, \mathrm{Cd}, \mathrm{Sn}, \mathrm{Cu}$ and $\mathrm{Zn}$ ) are summarized in Tab. 1. The heavy metal concentrations determined were based on sample dry weight.

Concentration of toxic and essential elements (mean $\pm \mathrm{SD}$, in $\mathrm{mg} \mathrm{kg}^{-1}$ dry wt)

Tab. 1 from tomatoes during processing

\begin{tabular}{|l|c|c|c|c|c|}
\hline \multicolumn{1}{|c|}{ Specification } & $\mathrm{Pb}$ & $\mathrm{Cd}$ & $\mathrm{Sn}$ & $\mathrm{Cu}$ & $\mathrm{Zn}$ \\
\hline $\begin{array}{l}\text { Tomatoes - } \\
\text { unprocessed }\end{array}$ & $0,2275 \pm 0,025$ & $0,0155 \pm 0,005$ & $0,100 \pm 0,082$ & $12,565 \pm 2,665$ & $4,142 \pm 0,439$ \\
\hline Tomatoes - whasing & $0,2400 \pm 0,022$ & $0,0150 \pm 0,003$ & $0,150 \pm 0,058$ & $12,525 \pm 1,533$ & $3,727 \pm 0,519$ \\
\hline $\begin{array}{l}\text { Mechanical } \\
\text { shredding }\end{array}$ & $0,1500 \pm 0,026$ & $0,0135 \pm 0,001$ & $0,125 \pm 0,050$ & $11,610 \pm 0,470$ & $3,517 \pm 1,003$ \\
\hline Preheating & $0,2200 \pm 0,045$ & $0,0125 \pm 0,001$ & $0,175 \pm 0,096$ & $11,187 \pm 0,025$ & $3,532 \pm 0,234$ \\
\hline $\begin{array}{l}\text { Concentration and } \\
\text { pasteurization } \\
\text { (finished product) }\end{array}$ & $0,1350 \pm 0,031$ & $0,0028 \pm 0,001$ & $0,200 \pm 0,082$ & $3,385 \pm 0,492$ & $2,565 \pm 0,091$ \\
\hline $\begin{array}{l}\text { Residue } \\
\text { (skin/seeds) }\end{array}$ & $0,2450 \pm 0,044$ & $0,0145 \pm 0,001$ & $0,225 \pm 0,096$ & $11,055 \pm 0,846$ & $3,362 \pm 0,536$ \\
\hline
\end{tabular}

Influence of technological process on lead content in tomatoes led to fluctuations in the content during subsequent processing. The results showed that the levels of $\mathrm{Pb}$ in all samples of tomatoes were between $0.2400 \mathrm{mg} \mathrm{kg}^{-1}$ in tomatoes after whasing and $0.1350 \mathrm{mg} \mathrm{kg}^{-1}$ in tomato broth. The stages of processing tomatoes: washing, mechanical shredding preheating, concentration and pasteurization, decreased successive the average concentration of cadmium residual up to $81.93 \%$, from $0.0155 \mathrm{mg} \mathrm{kg}^{-1}$ to $0.0028 \mathrm{mg} \mathrm{kg}^{-1}$.

Another chemical element from group of metals in samples of tomatoes investigated in the study is copper. Analyzed as a whole the results it is noted that the average concentration of $\mathrm{Cu}$ registered decreases significant by the concentration step followed by pasteurization of $69.74 \%$, from $11.187 \mathrm{mg} \mathrm{kg}^{-1}$ to $3.385 \mathrm{mg} \mathrm{kg}^{-1}$.

Like $\mathrm{Cu}, \mathrm{Zn}$ is an essential element for plants. Sufficient $\mathrm{Zn}$ is essential to neutralize the toxic effects of $\mathrm{Cd}$. In this study, maximum quantity of zinc was detected in tomatoes unprocessed $(4.142 \mathrm{mg}$ $\mathrm{kg}^{-1}$ ) while tomato broth had the lowest concentration $\left(2.565 \mathrm{mg} \mathrm{kg}^{-1}\right)$.

Tin content of tomatoes samples showed a significant increase by applying heat treatments. Quantitative tomato broth expressed a higher average concentration in tin $\left(0.100 \mathrm{mg} \mathrm{kg}^{-1}\right)$ compared to unprocessed tomatoes $\left(0,225 \mathrm{mg} \mathrm{kg}^{-1}\right)$.

Residual concentrations of $\mathrm{Pb}, \mathrm{Cd}, \mathrm{Cu}, \mathrm{Zn}$ and $\mathrm{St}$ of skin and seed residue from the processing of tomatoes recorded high values.

Tomatoes samples analyzed for $\mathrm{Hg}$ and $\mathrm{As}$ content have yielded values below the detection limit.

\section{Conclusion}

Tomato samples analyzed for average content $\mathrm{Pb}, \mathrm{Cd}, \mathrm{Cu}$ and $\mathrm{Zn}$ have resulted in values that were significantly reduced (except for residual tin) after processing into tomato broth.

\section{REFERENCES}

1. Beceanu, D. (2010). Tehnologia prelucrării legumelor şi fructelor. Cunoştiinţe de bază şi aplicaţii practice. Editura Pim, Iaşi.

2. Radwan M. A., Salama, A. K. (2006). Market basket survey for some heavy metals in Egyptian fruits and vegetables. Food and Chemical Toxicology. 44:1273-1278. 